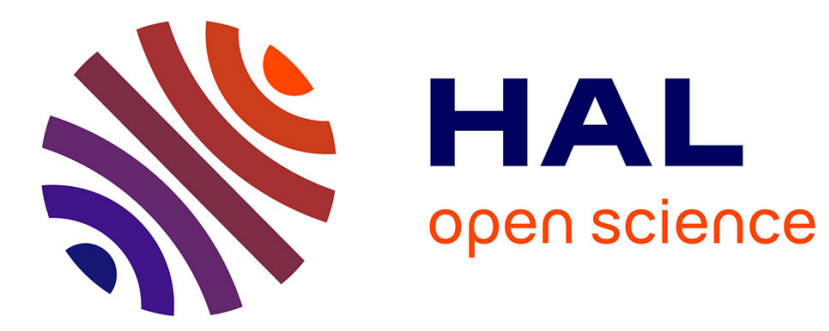

\title{
Space degradation of 3J solar cells: I-Proton irradiation
} Seonyong Park, Jacques C. Bourgoin, Hyeonseok Sim, Carsten Baur, Victor Khorenko, Olivier Cavani, Jérôme Bourcois, Sandrine Picard, Bruno Boizot

\section{To cite this version:}

Seonyong Park, Jacques C. Bourgoin, Hyeonseok Sim, Carsten Baur, Victor Khorenko, et al.. Space degradation of 3J solar cells: I-Proton irradiation. Prog.Photovol.Res.Appl., 2018, 26 (10), pp.778-788. 10.1002/pip.3016 . hal-01960379

\section{HAL Id: hal-01960379 \\ https://hal.science/hal-01960379}

Submitted on 2 Jan 2019

HAL is a multi-disciplinary open access archive for the deposit and dissemination of scientific research documents, whether they are published or not. The documents may come from teaching and research institutions in France or abroad, or from public or private research centers.
L'archive ouverte pluridisciplinaire HAL, est destinée au dépôt et à la diffusion de documents scientifiques de niveau recherche, publiés ou non, émanant des établissements d'enseignement et de recherche français ou étrangers, des laboratoires publics ou privés. 


\section{Space degradation of $3 \mathrm{~J}$ solar cells: I-Proton irradiation}

Seonyong Park ${ }^{1}$, Jacques C. Bourgoin ${ }^{1}$, Hyeonseok $\operatorname{Sim}^{1}$, Carsten Baur ${ }^{3}$, Victor Khorenko ${ }^{4}$, Olivier Cavani ${ }^{1}$, Jérôme Bourcois ${ }^{2}$, Sandrine Picard ${ }^{2}$, Bruno Boizot ${ }^{1}$

1 Laboratoire des Solides Irradiés, CNRS-UMR 7642, CEA-DRF-IRAMIS, Ecole Polytechnique, Université Paris-Saclay, Palaiseau Cedex 91120 , France

2 CSNSM, Université Paris-Sud, CNRS/IN2P3, Université Paris-Saclay, 91405 Orsay, France

3 European Space Agency, Keplerlaan 1, 2201AZ Noordwijk, The Netherlands

4 AZUR SPACE Solar Power GmbH, Theresienstr. 2, 74072 Heilbronn, Germany

To understand the influence of proton irradiation on lattice-matched GalnP/GaAs/Ge triple junction (TJ) solar cells under low intensity, low temperature (LILT) conditions, we investigated electrical behaviors of top, middle, and bottom component cells together with TJ cells under these conditions. Proton irradiations with energies of $1 \mathrm{MeV}$ and fluences ranging from $2 \times 10^{10}$ to $1.6 \times 10^{12} \mathrm{~cm}^{-2}$ were performed at temperatures ranging from 100 to $300 \mathrm{~K}$. Our study reveals that any of the 3 subcells can become the current limiting cell in the TJ cell, depending on temperature and fluence. In particular, remarkable degradation of the bottom cell at low temperature can make this subcell the current limiting in a TJ cell even for limited fluences. The results indicate that the defect distribution is non-uniform for low temperature irradiation.

Funding information

EMIR federation, Grant/Award Numbers: $15-5727$ and 4000109645; European Space Agency

\section{I INTRODUCTION}

State-of-the-art solar cells used for space missions are lattice-matched triple junction (TJ) cells, composed of GalnP, GaAs, and Ge-based subcells monolithically connected in series, because they demonstrate the highest efficiency so far. ${ }^{1,2}$ Moreover, they exhibit the best radiation resistance compared to other types of cells.,4 Their behavior under electron and proton irradiations at room temperature has been studied extensively. ${ }^{5-11}$

These TJ cells are also now used for interplanetary and deep space missions, whose typical environment is often referred to as LILT (for low intensity, low temperature) conditions. However, the understanding of their behavior under particle irradiation at low temperature is still in infancy. Because of the difficulty to perform irradiation testing at low temperature followed by in-situ electrical data acquisition under solar illumination, this understanding has been deduced from low temperature measurements performed after room temperature irradiation. ${ }^{12-14}$ With the exception of 1 attempt, ${ }^{15,16}$ the only studies of low temperature irradiation with in-situ measurements have been performed on TJ cells produced by AZUR SPACE. ${ }^{17-20}$

Preliminary results ${ }^{17}$ suggested that the electrical behavior of these TJ cells at low temperature was independent from the temperature at which irradiations were performed. However, detailed analysis of the data acquired at low temperature reveals that several phenomena such as defect annealing, junction behavior under stress, and tunneling have to be taken into account, the phenomena which are not observable in case of room temperature irradiation. This motivated us to perform a detailed study of the degradation of $\mathrm{TJ}$ cells and their respective component cells at temperatures ranging from 100 to $300 \mathrm{~K}$. The study presented here is limited to the case of proton irradiation; the case of electron irradiation will be presented in a dedicated publication. ${ }^{21}$

\section{I EXPERIMENTAL}

The realization of low temperature current-voltage (I-V) measurements of solar cells irradiated at low temperature requires a cryostat setup allowing to position the cell perpendicular to the irradiating beam of the proton accelerator and then to the illumination source. The vacuum $\left(10^{-7} \mathrm{mbar}\right)$ must be the same in the cryostat and the accelerator because even a thin foil of separation would absorb incoming protons. Thus, all measurements are also performed in the same vacuum condition as that of the proton irradiation. Our cryostat 
setup consists of a chamber equipped with a vacuum flange for mounting to the beam line, a quartz window for the illumination, the cell support designed for a cell size of $2 \times 2 \mathrm{~cm}^{2}$, temperature sensors, and electrical wiring for performing electrical measurements. Cooling and temperature stabilization are realized by a liquid nitrogen flow and an ohmic heater which is incorporated into the support. This support is made of pure copper to allow good thermal conduction at low temperature. The temperature is monitored with a temperature controller (from Lakeshore). Temperatures in the range 80 to $400 \mathrm{~K}$ can be achieved. Electrical measurements are conducted using a (Keithley) sourcemeter.

As the temperature decreases, the temperature difference between the support and the cell increases. It is necessary, therefore, to measure directly the temperature of the cell using a calibrated sensor. For this purpose, a CERNOX temperature sensor, soldered on the surface of a dummy cell, is used to establish the relationship between the temperatures of the support and of the cell. The reported temperatures here are the ones delivered by the CERNOX sensor.

The solar simulator delivering the illumination has been originally realized, together with the cryostat, to perform tests on the Si solar cells designed for the Rosetta mission. ${ }^{22-24}$ It has been continuously improved since. It consists of a Xenon (Xe) lamp coupled to a Quartz Tungsten Halogen lamp through a cold filter which eliminates the low energy part of the Xe and the high energy part of the Quartz Tungsten Halogen. Calibration of the simulator is performed by adjusting the intensities of the 2 lamps using corresponding GalnP (top), GaAs (middle), and Ge (bottom) component cells, ie, single-junction cells having the same structure as the TJ cell but with only 1 junction being electrically active, as illustrated in Figure 1. In this study, we adapted the simulator to the Jupiter relevant conditions which are 3.7\% AMO. The spectrum of the solar simulator is recorded using a low-resolution spectrometer (a prism, in order to integrate the Xe peaks) equipped with a lock-in amplifier and a Ge detector (see Figure 2).

The aperture of the proton beam is $8 \mathrm{~cm}^{2}$ (covering the whole area of the cell). The proton energy used is $1 \mathrm{MeV}$ with a flux of $4 \times 10^{9} \mathrm{~cm}^{-2} \mathrm{~s}^{-1}$ and fluences ranging from $2 \times 10^{10} \mathrm{~cm}^{-2}$ to $1.6 \times 10^{12} \mathrm{~cm}^{-2}$. A SRIM simulation of the TJ structure of $\mathrm{Ga}_{0.51} \ln _{0.49} \mathrm{P}$ $(0.6 \mu \mathrm{m}) / \mathrm{GaAs}(2.6 \mu \mathrm{m}) / \mathrm{Ge}(140 \mu \mathrm{m})$ has been carried out (see Figure 3) using the SRIM-2013 software developed by James F. Ziegler. ${ }^{25} \mathrm{~A}$ depth profile of the proton energy loss is plotted up to

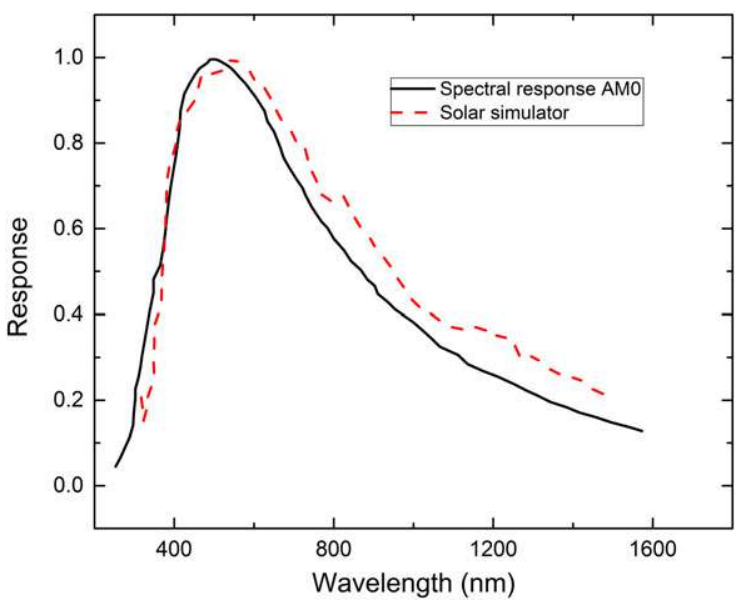

FIGURE 2 AMO solar simulator spectrum monitored with a $\mathrm{Ge}$ detector [Colour figure can be viewed at wileyonlinelibrary.com]

$8 \mu \mathrm{m}$ from the surface of the top cell. The energy of incident proton was set to $1 \mathrm{MeV}$, and the threshold energy for displacement $\left(T_{D}\right)$ was assumed as $21 \mathrm{eV}$ for the 3 materials. The average energy loss $\left(E_{\text {Loss }}\right)$ of the protons in junctions of each layer is between 5 and $7 \mathrm{eV} /$ Angstrom. According to the SRIM coding, protons that have 1$\mathrm{MeV}$ energy are stopped within the depth of $11.5 \mu \mathrm{m}$, sufficiently far from the active region of Ge bottom cell.

\section{3 | RESULTS}

\subsection{Irradiation of TJ cells at low temperature.}

$\mathrm{TJ}$ cells were irradiated by $1-\mathrm{MeV}$ protons with fluences varying from $1 \times 10^{11}$ to $5.4 \times 10^{11} \mathrm{~cm}^{-2}$. Irradiations and measurements were performed at $123 \mathrm{~K}$. The number of cells irradiated in each condition varied from 3 to 13. Relative changes of $\mathrm{I}_{\mathrm{SC}}, \mathrm{V}_{\mathrm{OC}}$, and $\mathrm{P}_{\mathrm{MAX}}$ values after irradiation expressed, as remaining factor (RF), are presented in Figure 4. The change of RF $\left(I_{S C}\right)$ versus fluence is small below typically $2.7 \times 10^{11} \mathrm{~cm}^{-2}$, whereas it suddenly increases reaching 0.93 at $5.4 \times 10^{11} \mathrm{~cm}^{-2}$. This observation suggests that there could be a critical condition corresponding to a modification of the degradation mechanism (a change of the subcell which limits the current). As to

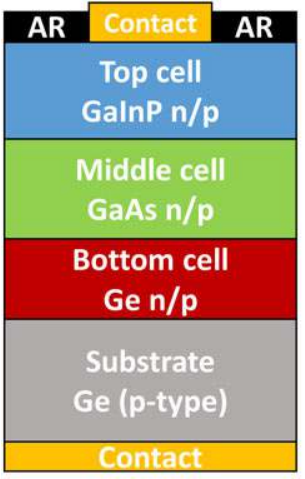

Triple Junction cell

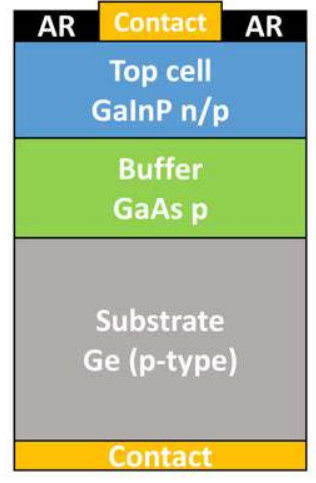

Top

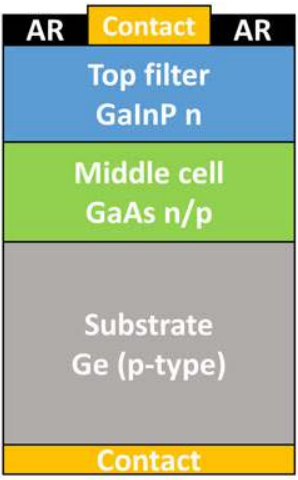

Middle

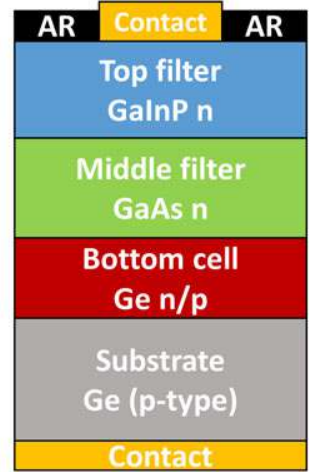

Bottom

FIGURE 1 Description of the triple junction and component cells used in this study [Colour figure can be viewed at wileyonlinelibrary.com] 
(a)

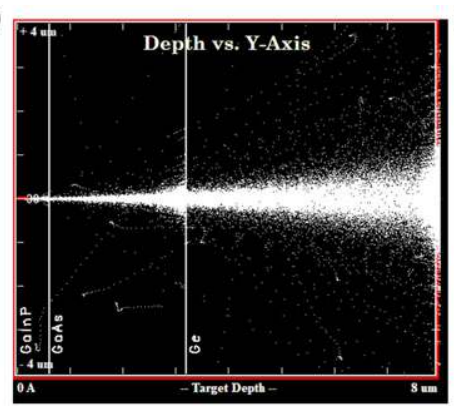

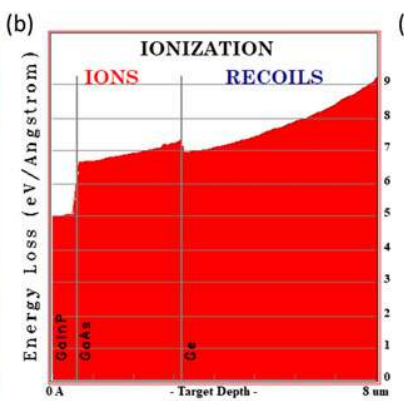

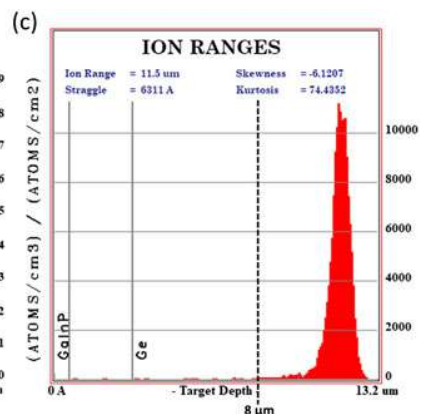

FIGURE 3 SRIM simulation with $1 \mathrm{MeV}$ proton irradiation on the TJ cell used in this study. A, Profile of ion propagation, B, ionization energy loss versus target depth, and $C$, ion ranges. Displacement energy $\left(T_{D}\right)$ of $21 \mathrm{eV}$ is applied for 3 materials [Colour figure can be viewed at wileyonlinelibrary.com]

(a)

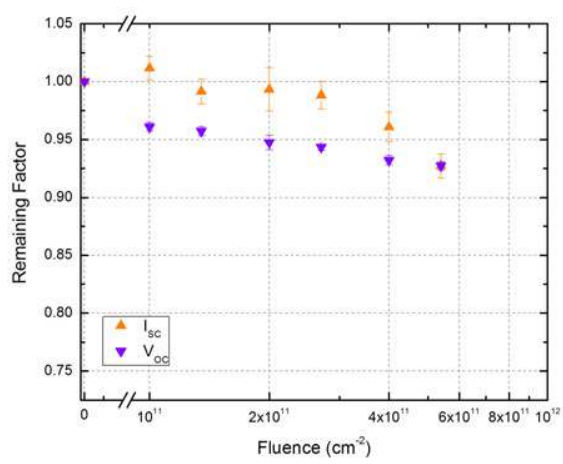

(b)

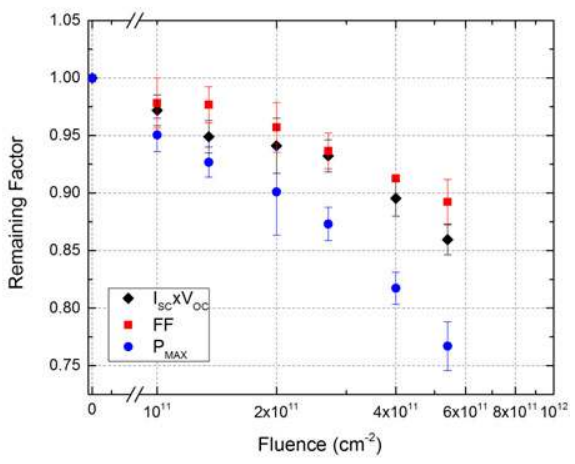

FIGURE 4 Remaining factor of key parameters for 1-MeV proton irradiation of $\mathrm{TJ}$ solar cells at $123 \mathrm{~K}$ : A, open-circuit voltage $\mathrm{V}_{\mathrm{OC}}$, short-circuit current $\mathrm{I}_{\mathrm{SC}}$ and $\mathrm{B}$, product $\mathrm{I}_{\mathrm{SC}} \times \mathrm{V}_{\mathrm{OC}}$, fill factor $\mathrm{FF}$ and maximum power $\mathrm{P}_{\text {MAX }}$ [Colour figure can be viewed at wileyonlinelibrary.com]
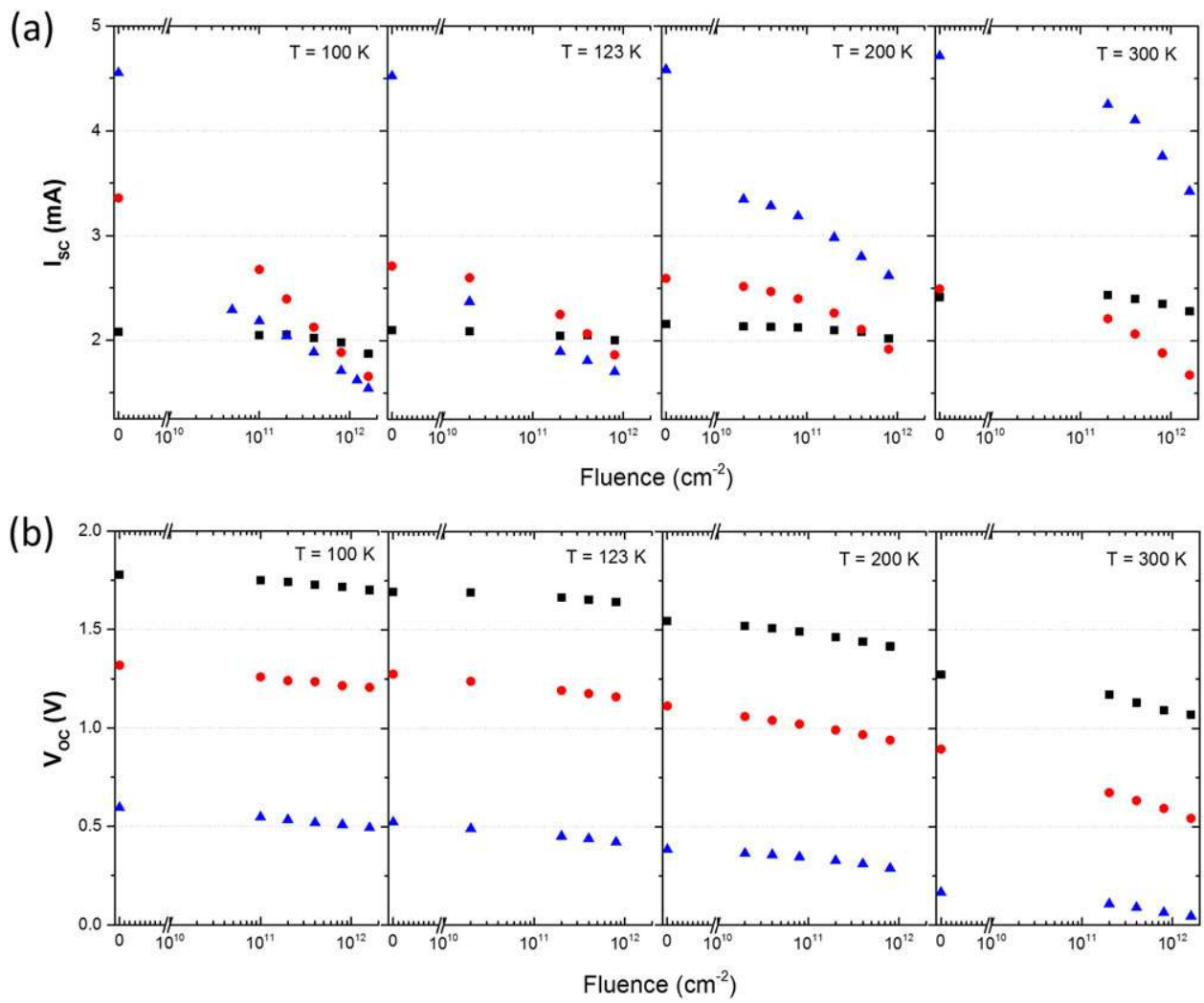

FIGURE 5 Fluence dependences of $A, I_{S C}$ and $B, V_{O C}$ of component cells at 100, 123, 200, and $300 \mathrm{~K}$ irradiated at $1 \mathrm{MeV}$ with a flux of $4 \times 10^{9}$ $\mathrm{cm}^{-2} \mathrm{~s}^{-1}$. Black square, red circle, and blue triangle indicate top, middle, and bottom component cells, respectively [Colour figure can be viewed at wileyonlinelibrary.com] 
$\mathrm{RF}\left(\mathrm{V}_{\mathrm{OC}}\right)$, it decreases regularly as a function of fluence, after an initial step for the lowest fluence used. However, RF ( $\left.\mathrm{P}_{\mathrm{MAX}}\right)$ decreases more rapidly than the product $I_{S C} \times V_{O C}$, as it should vary if the fill factor (FF) was independent of the fluence. At the highest fluence, RF ( $P_{\text {MAX }}$ ) is approximately 0.77 suggesting that there seems to be another source of degradation, besides $\mathrm{I}_{\mathrm{SC}}$ and $\mathrm{V}_{\mathrm{OC}}$, affecting the FF.

\section{2 | Irradiation of component cells at various temperatures}

The investigation of component cells was performed to determine the changes of the key parameters associated with each cell as a function of fluence in the temperature range 100 to $300 \mathrm{~K}$. Here, we focus on the changes of $I_{S C}$ and $V_{O C}$.

Accumulative irradiations were carried out on top, middle, and bottom component cells at 100,123, 200, and $300 \mathrm{~K}$. Figure $5 \mathrm{~A}$ shows the changes of $\mathrm{I}_{\mathrm{SC}}$ as a function of fluence. The top cell appears to exhibit a smaller degradation than the middle cell. At room temperature, because BOL $I_{S C}$ values of a top cell are slightly smaller than that of the middle cell, the top cell is actually the current limiting cell in the TJ cell. However, the middle cell becomes the current limiting cell after irradiation with a fluence of approximately $10^{11} \mathrm{~cm}^{-2}$ because its degradation is stronger than that of the top cell. For lower temperatures, the cells act differently: when the temperature decreases, $I_{S C}$ of the top cell decreases while that of the middle cell apparently increases. As a result, a higher fluence $\left(5 \times 10^{11} \mathrm{~cm}^{-2}\right)$ is required to make $I_{S C}$ of the middle cell lower than that of the top cell. The bottom cell has a much higher BOL $\mathrm{I}_{\mathrm{Sc}}$ value compared to other 2 cells, so that, at 200 and $300 \mathrm{~K}$, in the TJ cell, the bottom cell does not become the current limiting cell even at high fluences. However, at 123 and $100 \mathrm{~K}$, the value of $\mathrm{I}_{\mathrm{SC}}$ of the bottom cell decreases abruptly: the large drop of $I_{S C}$ occurs for a very small fluence $\left(2 \times 10^{10} \mathrm{~cm}^{-2}\right)$, partly at least because of the photon recycling effect, $\mathrm{PRE}^{26}$ (an effect not present in the TJ cell), as we shall see below. Thus, the bottom cell will become current limiting in the $\mathrm{TJ}$ cell. As to the $\mathrm{V}_{\mathrm{OC}}$ degradations of the 3 component cells, they are presented in Figure 5B.

Because the degradation of the bottom component cell appears to depend strongly on the irradiation temperature, we performed additional irradiations of these cells. The results are shown in Figure 6. Once corrected to remove the contribution of the PRE, they show that RF ( $\left.\mathrm{I}_{\mathrm{SC}}\right)$ is strongly temperature dependent (see Figure 7). The contribution of the PRE is deduced from the difference of $I_{S C}$ of the bottom cell between a non-irradiated cell and a cell irradiated with a fluence of $2 \times 10^{10} \mathrm{~cm}^{-2}$ (known to cancel photon recycling while introducing a negligible degradation). Figure 8 shows the contribution of PRE versus temperature, difference of $I_{S C}$ between non-irradiated and irradiated bottom cells.

The comparison between the degradations of $\mathrm{I}_{\mathrm{SC}}$ and $\mathrm{V}_{\mathrm{OC}}$ of the TJ cells with that deduced from the degradation of component cells (by selecting the minimum value of $\mathrm{I}_{\mathrm{SC}}$ among the component cells and adding their $V_{O C}$ values) is given in Figure 9. It shows that for $V_{O C}$ reasonable fits are obtained, which implies that the prediction of the $V_{\mathrm{OC}}$ degradation of TJ cells can be reasonably well deduced from that of the component cells. For the $I_{S C}$ degradation, the fits at low temperature are not satisfying because of the low shunt resistance of the

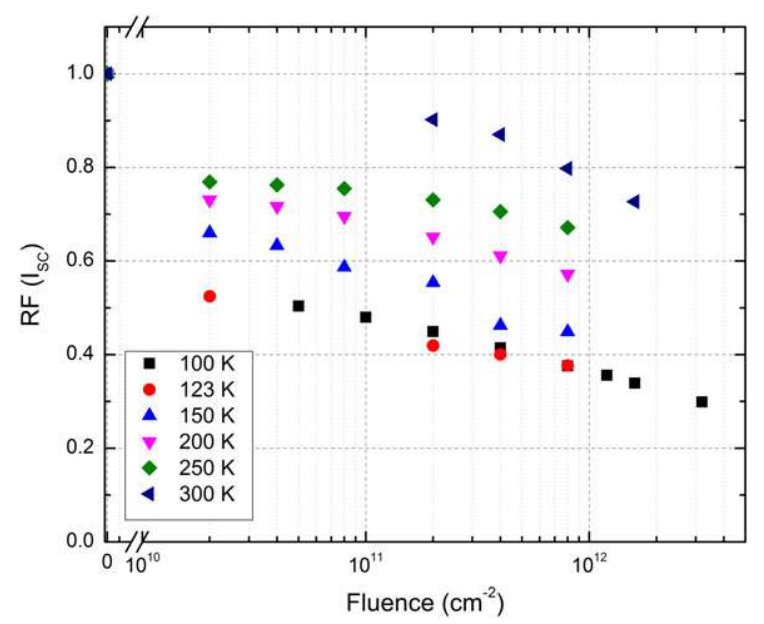

FIGURE 6 ISC remaining factor of bottom component cells irradiated at various temperatures with a flux of $4 \times 10^{9} \mathrm{~cm}^{-2} \mathrm{~s}^{-1}$ (the results are not corrected for PRE) [Colour figure can be viewed at wileyonlinelibrary.com]

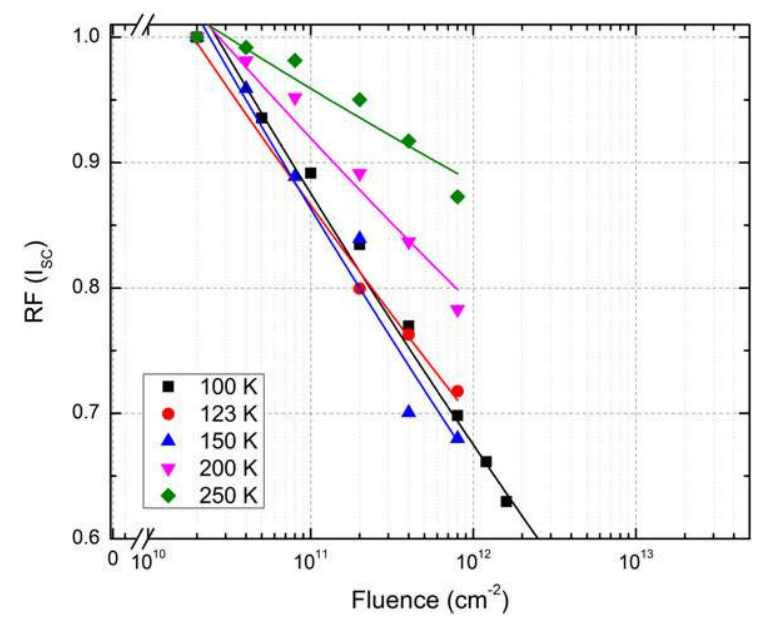

FIGURE 7 ISC remaining factor of bottom component cells irradiated with $1 \mathrm{MeV}$ protons at $100,123,150,200$, and $250 \mathrm{~K}$ after correction for PRE. Nonlinear curve fit is applied for each temperature [Colour figure can be viewed at wileyonlinelibrary.com]

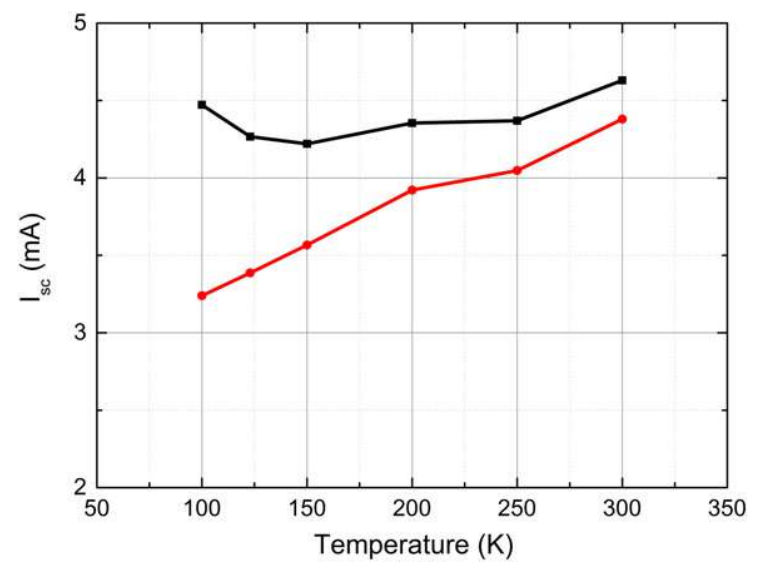

FIGURE 8 BOL (black square) and EOL (red circle) $I_{S C}$ of bottom component cells versus temperature after $1-\mathrm{MeV}$ irradiation with a fluence of $2 \times 10^{11} \mathrm{~cm}^{-2}$ and annealing at $300 \mathrm{~K}$, illustrating the contribution of the photon recycling effect [Colour figure can be 

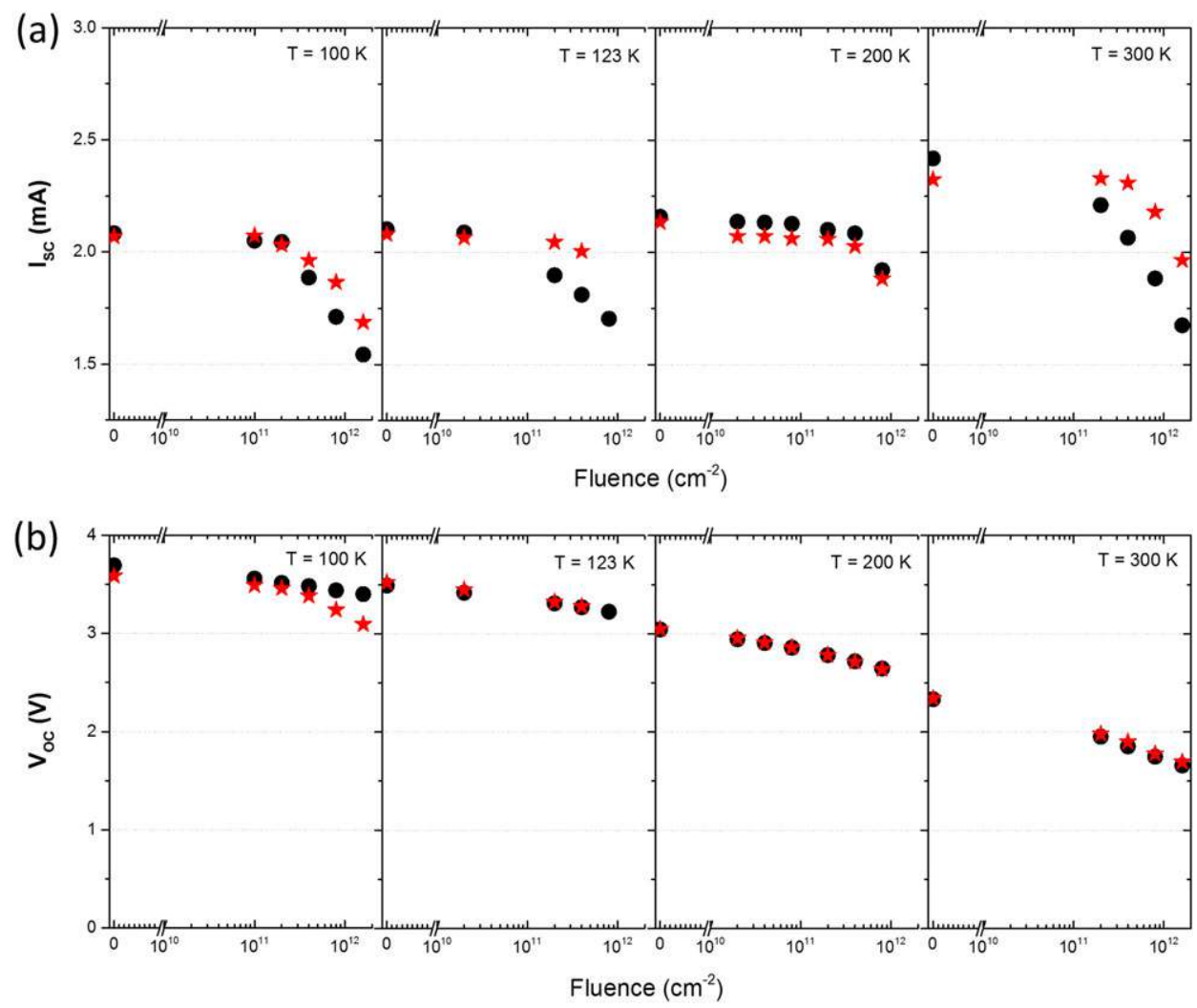

FIGURE 9 Comparison of the degradations of TJ cells with that deduced from the degradation of component cells: $A, I_{S C}$ and B, $V_{O C}$ at 100,123 , 200 , and $300 \mathrm{~K}$ : Black circle and red star indicate data obtained from component cells and TJ cells, respectively [Colour figure can be viewed at wileyonlinelibrary.com]

bottom cell. In those cases, where the bottom cell would be the current limiting cell (according to Figure 3A), the bottom cell in the $3 \mathrm{~J}$ cell is driven in reverse at $0 \mathrm{~V}$. Then, when the $\mathrm{I}-\mathrm{V}$ curve has a steep slope (due to the low shunt resistance), the $I_{S C}$ of the triple-junction cell is higher compared to the single bottom component cell. Mostly, the current limiting cell at $0 \mathrm{~V}$ is then even 1 of the other 2 subcells.

\section{3 | Isochronal annealing in component cells}

Because the component cells exhibit different temperature dependent behaviors, we performed isochronal annealing procedures following irradiation with a fluence of $1.6 \times 10^{12} \mathrm{~cm}^{-2}$ at $100 \mathrm{~K}$. Figure $10 \mathrm{~A}$ shows the RFs of $\mathrm{I}_{\mathrm{SC}}, \mathrm{V}_{\mathrm{OC}}$, and $\mathrm{P}_{\mathrm{MAX}}$ of the 3 component cells measured at $100 \mathrm{~K}$ after each annealing step. The annealing was carried out at 150,190, 240, and $300 \mathrm{~K}$ during 5 minutes for the top and middle cells. For the bottom cell, the annealing temperature was increased by $18 \mathrm{~K}$ after the previous step. The annealing time was 5 minutes as well (see Figure 10B,C). The top and middle cells did not show any significant recovery throughout the temperature range 100 to $300 \mathrm{~K}$. However, changes of $\mathrm{I}_{\mathrm{SC}}$ and $\mathrm{V}_{\mathrm{OC}}$ values of the bottom cell result in a recovery of $\mathrm{RF}\left(\mathrm{P}_{\mathrm{MAX}}\right)$ from 0.25 to 0.41 , with 2 stages centered around 125 and $250 \mathrm{~K}$.

\subsection{Electrical characteristics of irradiated cells at low temperature}

Besides usual degradations of $\mathrm{I}_{\mathrm{SC}}$ and $\mathrm{V}_{\mathrm{OC}}$, $\mathrm{TJ}$ cells exhibit, in addition to the degradation induced by minority carrier recombination induced by the defects, a degradation associated with another cell parameter, which is only observable under illumination. Figure 11 shows the comparison between I-V characteristics under illumination (LIV) and in dark (DIV) after irradiation with a fluence of $1.6 \times 10^{12} \mathrm{~cm}^{-2}$. The DIV curve is shifted by $I_{S C}$, so that the DIV and LIV curves exhibit the same current at $V=0$. Before irradiation, these 2 curves overlap perfectly. However, after irradiation, the current under illumination starts to increase as a function of voltage while the dark current maintains its original value. This phenomenon results in a significant decrease of FF after irradiation, as noticed in the Section 3.1.

The same experiment has also been carried for all 3 component cells. As shown in Figure 12, only at EOL condition, we observe a discrepancy between LIV and shifted DIV curves for the top and middle cells. Within measurement accuracy, this effect is not observed for the bottom cell. Hence, the decrease of the photo current under illumination as a function of voltage in a TJ cell originates at least from the top and (or) middle subcells.

\section{4 | DISCUSSION AND ANALYSIS}

\section{1 | Temperature and fluence dependences of the degradation}

As shown in Figure $5 \mathrm{~A}$, in $\mathrm{BOL}$ condition, the 3 component cells behave differently as a function of temperature. The $I_{S C}$ values of top component cell decrease gradually from approximately 2.42 to $2.05 \mathrm{~mA}$ as the temperature goes down from 300 to $100 \mathrm{~K}$. As briefly 
(a)

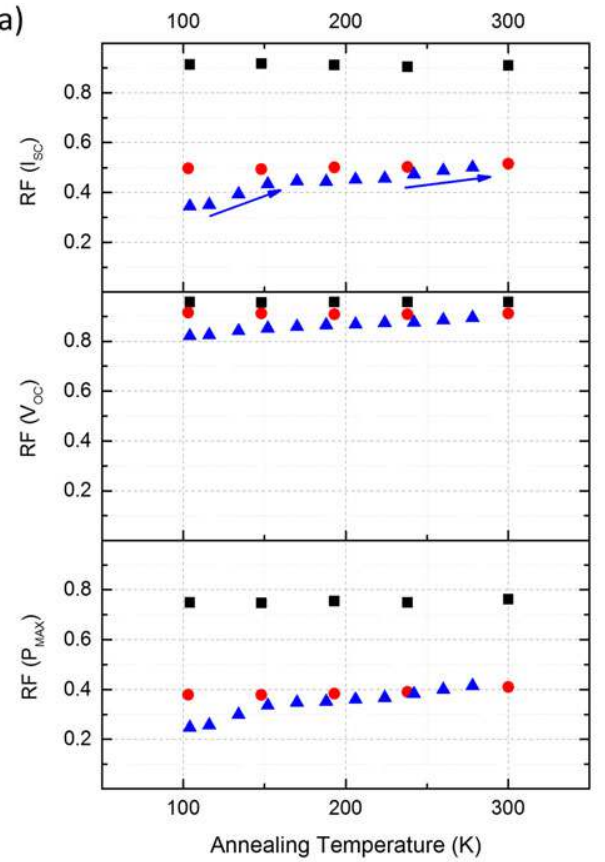

(b)

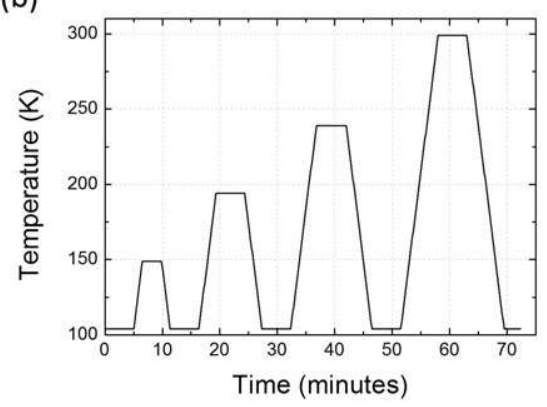

(c)

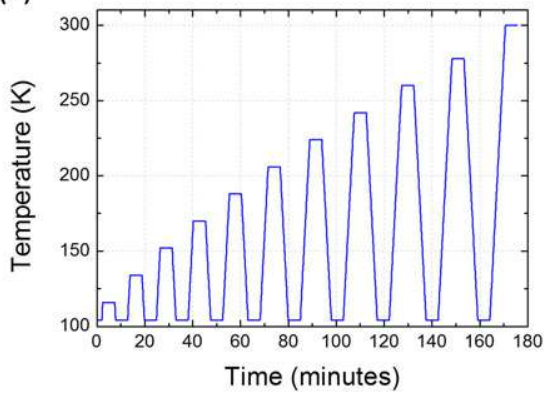

FIGURE 10 A, Remaining factors of $\mathrm{I}_{\mathrm{SC}}, \mathrm{V}_{\mathrm{OC}}$, and $\mathrm{P}_{\mathrm{MAX}}$ of proton irradiated $\left(1 \mathrm{MeV}, 1.6 \times 10^{12} \mathrm{~cm}^{-2}\right)$ component cells during isochronal annealing stages: Black square-Top, red circle-Middle, blue triangle-Bottom cells, respectively. Temperature profiles of isochronal annealing stages are represented for B, top and middle cells and C, bottom cell [Colour figure can be viewed at wileyonlinelibrary.com]

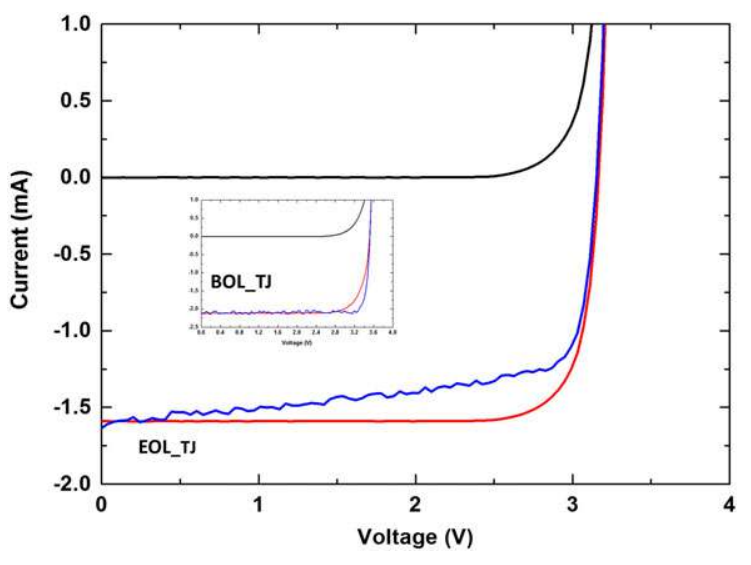

FIGURE 11 BOL (inset) and EOL I-V characteristics of a TJ cell irradiated with $1.6 \times 10^{12} \mathrm{~cm}^{-2}$ at $123 \mathrm{~K}$ (black line: dark I-V, red line: dark I-V $+I_{S C}$ (EOL), blue line: light I-V) [Colour figure can be viewed at wileyonlinelibrary.com]

explained in Section 3.2, the temperature behavior is not gradual: $I_{\mathrm{SC}}$ of the middle cell decreases from 300 to $200 \mathrm{~K}$ and increases again from 200 to $100 \mathrm{~K}$; in the bottom cell, this transition occurs around $150 \mathrm{~K}$. This behavior is due to the existence of the temperature dependent PRE in these cells (this is the reason why it is different in single cells ${ }^{27}$ ).

The rates of degradation of the components cells are different and depend on the temperature. Consider the $\mathrm{I}_{\mathrm{SC}}$ values: the top cell exhibits a small degradation below $10^{12} \mathrm{~cm}^{-2}$; the middle cell exhibits a significant degradation from the lowest fluence: around $20 \%$ at 300 and $200 \mathrm{~K}$, increasing to approximately $50 \%$, at $100 \mathrm{~K}$. As to the bottom cell, the sharp drop for the lowest fluence at low temperature must correspond partially to the cancellation of PRE, which is known to disappear after irradiation with the lowest fluence (see Figure 8).
However, as we shall now examine, the change of $\mathrm{I}_{\mathrm{SC}}$ in this cell is strongly temperature dependent, apparently more than expected when taking defect annealing into account. Note in particular, that at $300 \mathrm{~K}, \mathrm{I}_{\mathrm{SC}}$ decreases by approximately $1 \mathrm{~mA}$ when the fluence increases from $1 \times 10^{11}$ to $1.6 \times 10^{12} \mathrm{~cm}^{-2}$. This result is apparently surprising because it is in contradiction with results of electron irradiation at $300 \mathrm{~K}$ : no change of $\mathrm{I}_{\mathrm{SC}}$ is then observed ${ }^{21}$ in identical bottom cells irradiated with $1-\mathrm{MeV}$ electrons for fluences ranging from $5 \times 10^{14}$ to $2 \times 10^{15} \mathrm{~cm}^{-2}$. Using SR-NIEL Calculator, ${ }^{28}$ the NIEL values of $1 \mathrm{MeV}$ proton and electron in Ge (assuming that $T_{D}$ is $21 \mathrm{eV}$ ) are obtained as $4.9 \times 10^{-2}$ and $1.1 \times 10^{-5} \mathrm{MeVcm}^{2} / \mathrm{g}$, respectively. Therefore, the calculated displacement damage doses are approximately $4.9 \times 10^{9}$ to $7.8 \times 10^{10} \mathrm{MeV} / \mathrm{g}$ for protons and $5.5 \times 10^{9}$ to $2.2 \times 10^{10} \mathrm{MeV} / \mathrm{g}$ for electrons, respectively.

We therefore performed a systematic study of $I_{S C}$ versus fluence and temperature to investigate the mechanism of degradation in the bottom cell. The results are shown in Figure 13 under the form $\mathrm{C}=1-\mathrm{RF}\left(\mathrm{I}_{\mathrm{SC}}\right)$, a quantity which reflects directly the concentration of defects introduced by the irradiation versus temperature with several fluences.

This figure illustrates that $C$ varies regularly with temperature, a behavior not expected, if it is the result of defect annealing ${ }^{29:}$ the amplitude of the annealing stage around $125 \mathrm{~K}$ observed in the isochronal annealing procedure (see Figure 10), of the order of 0.1 , is not observed in the figure.

On the other hand, the temperature dependence of the fluence (Figure 14) required to reach a given degradation level and hence, a given defect concentration, changes over nearly 2 orders of magnitude between 150 and $250 \mathrm{~K}$, while it is not significantly changed between 100 and $150 \mathrm{~K}$, which is also not compatible with defect 


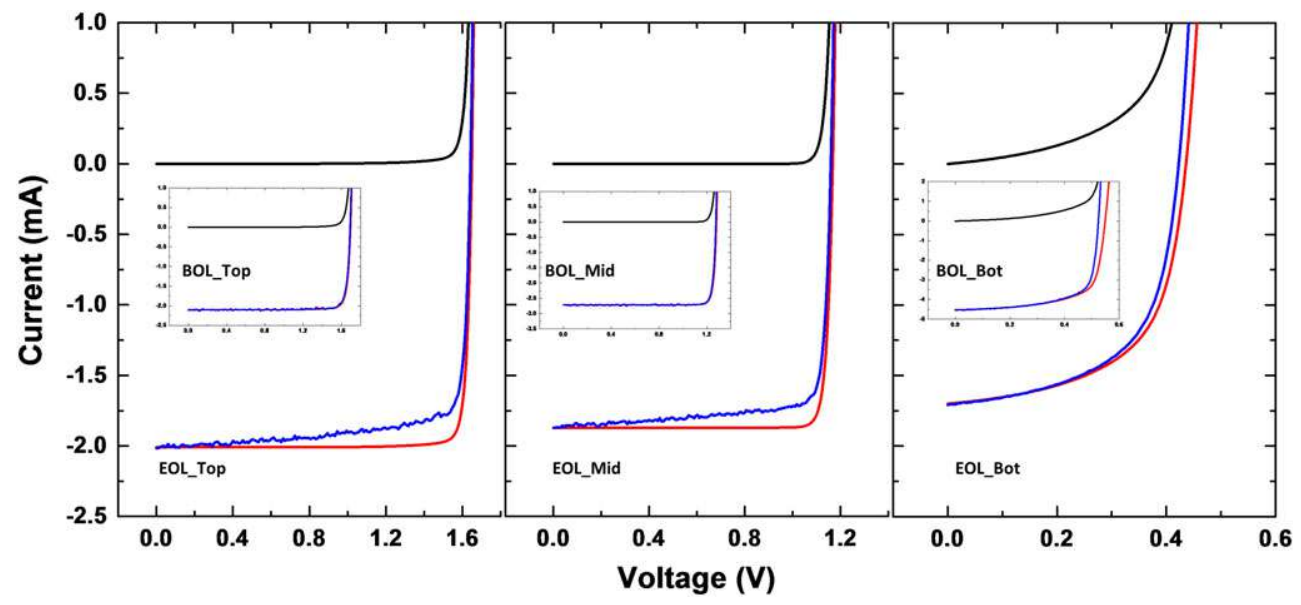

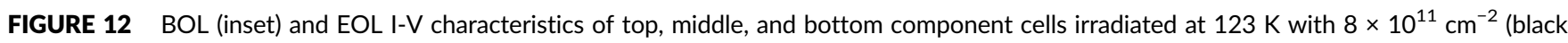
line: dark I-V, red line: dark I-V + ISC (EOL), blue line: light I-V) [Colour figure can be viewed at wileyonlinelibrary.com]

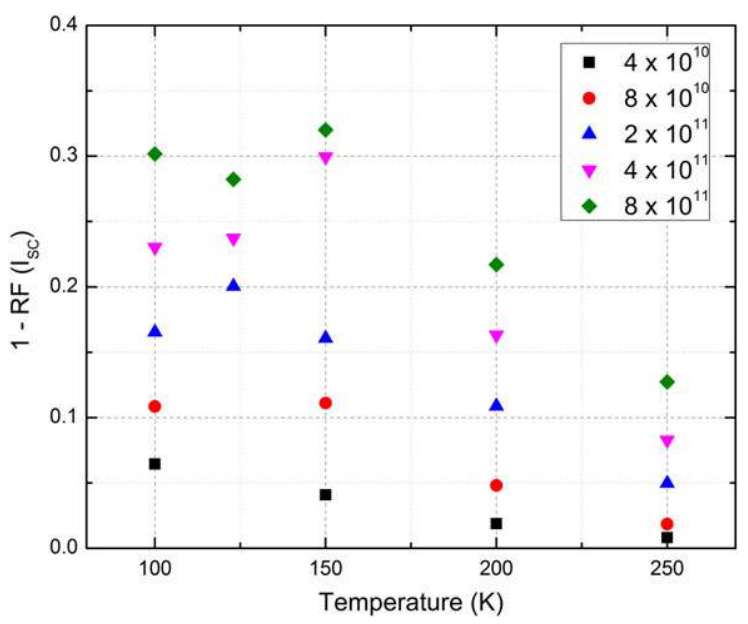

FIGURE 131 - RF ( $\left.I_{S C}\right)$ versus temperature in bottom component cells irradiated with various fluences $\left(\mathrm{cm}^{-2}\right)$ [Colour figure can be viewed at wileyonlinelibrary.com]

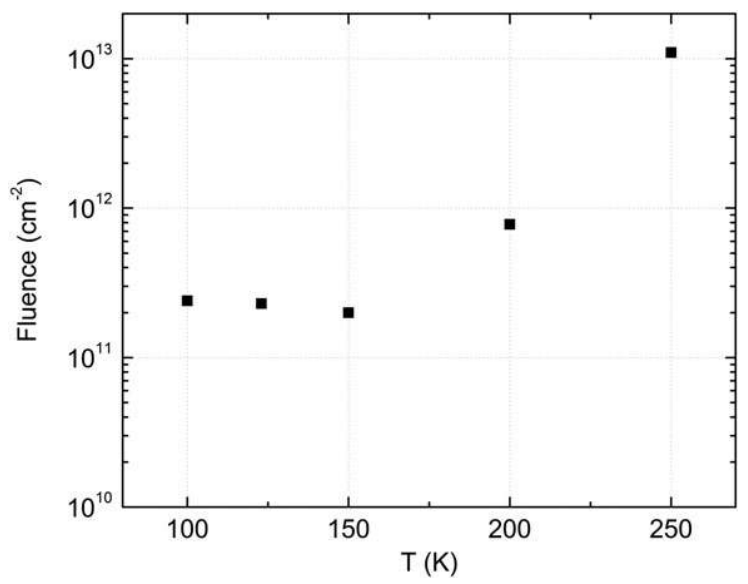

FIGURE 14 Logarithm of the fluence versus temperature for $\mathrm{RF}\left(\mathrm{I}_{\mathrm{SC}}\right)=0.8$ of bottom component cells. Data points were obtained from the nonlinear curve fit of Figure 5 at each temperature
That electron irradiation at $300 \mathrm{~K}$ does not produce any degradation is consistent with results of old studies where no defects were detected in p-type $\mathrm{Ge}^{29}$ material with which the cells are produced (by As diffusion). This is understood by the mobility of the primary defects, interstitials, and vacancies (V-I pairs), which recombine already at $4 \mathrm{~K} .{ }^{29} \mathrm{In}$ the case of proton irradiation, the situation is quite different: the V-I pairs are not uniformly distributed but decorate the proton tracks; they are hence in large, local, concentration and instead of recombining, they form complexes (such as divacancies) which are stable. These complexes being charged produce space charge regions of cylindrical shape along the tracks which repel the photocarriers.

Hence, the degradation in the bottom cell, at least at low temperature, is not the result of minority carrier recombination on defects but corresponds to the decrease of the effective cell area.

As shown in Figure 15, when the bottom component cell is irradiated with protons, one can see that there is no increase of the saturation current. This indicates that no defects are introduced in the active area of the cell.

The degradation model is therefore the following: an incoming proton produces atomic displacements, ie, defects, along its track. Some of these defects are charged and consequently create a space

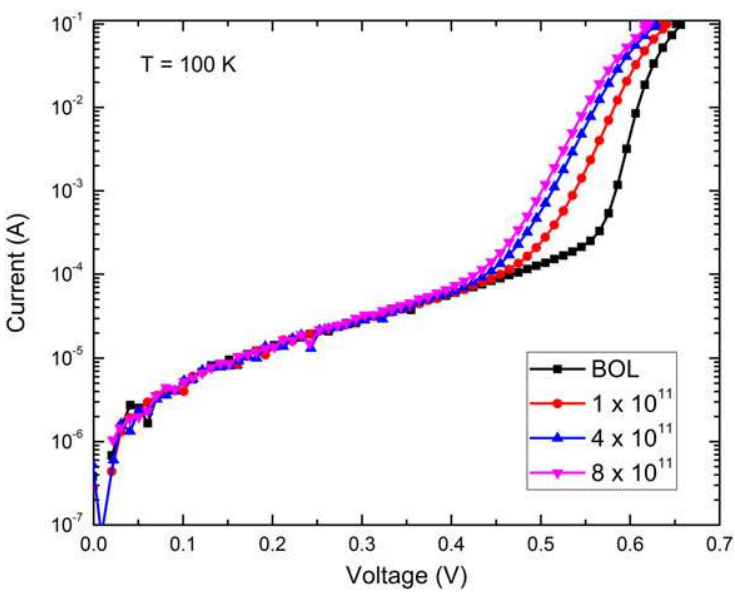

FIGURE 15 Dark I-V characteristics of a bottom component cell at $100 \mathrm{~K}$ irradiated with various fluences $\left(\mathrm{cm}^{-2}\right)$ [Colour figure can be viewed at wileyonlinelibrary.com] 
charge region which can be approximated by a cylindrical volume $V$ of radius $r$, perpendicular to the surface of the cell. The radius $r$ is a function of the charge $Q$ trapped on the defects and of the doping concentration $N$ in the material. Equality between the charge $Q$ and the opposite charge $N V$ developed in the space charge region makes that $r$ is a function of $Q$ and $N$ at a given temperature.

The space charge regions decorating the proton tracks repel the minority carriers generated by the illumination and, thus, reduce the effective active area $S$ of the cell. Under the introduction of $\varphi$ protons (per unit surface):

$$
S=S_{0}-\varphi S_{0} \pi r^{2}
$$

where $S_{0}$ the cell area, so that $S$ can be expressed by

$$
\frac{S}{S_{0}}=1-\varphi \pi r^{2}
$$

The photocurrent being proportional to the active area of the cell degrades at the rate $S / S_{0}$ such that

$$
1-R F(I s c)=1-\frac{S}{S_{0}}=\varphi \pi r^{2}
$$

The temperature dependence of $\mathrm{RF}\left(\mathrm{I}_{\mathrm{SC}}\right)$ should reflect that of $r^{2}$ which can be approximated by the fact that the carriers (of energy $\mathrm{kT}$ ) are repelled by the potential of the charge $\mathrm{Q}$ (proportional to $r$ ${ }^{-1}$ ). Thus, $R F\left(I_{S C}\right)$ should (to first order) vary linearly with $T^{-2}$. Figure 16 illustrates that this is approximately the case when the temperature is large enough.

Finally, according to this picture, the degradation of $V_{O C}$ is expected, as observed, to be small because it is not dependent on the cell area.

In conclusion, the experimental data concerning the bottom cell indicate that the degradation induced by proton irradiation at low temperature in $\mathrm{Ge}$ is governed by space charged regions located around proton tracks, which implies that the resulting distribution of the induced defects is not uniform.

The bottom cell appears to become the current limiting cell below $123 \mathrm{~K}$ for a fluence larger than approximately $10^{11} \mathrm{~cm}^{-2}$. Prediction of the nature of the current limiting cell versus temperature is not

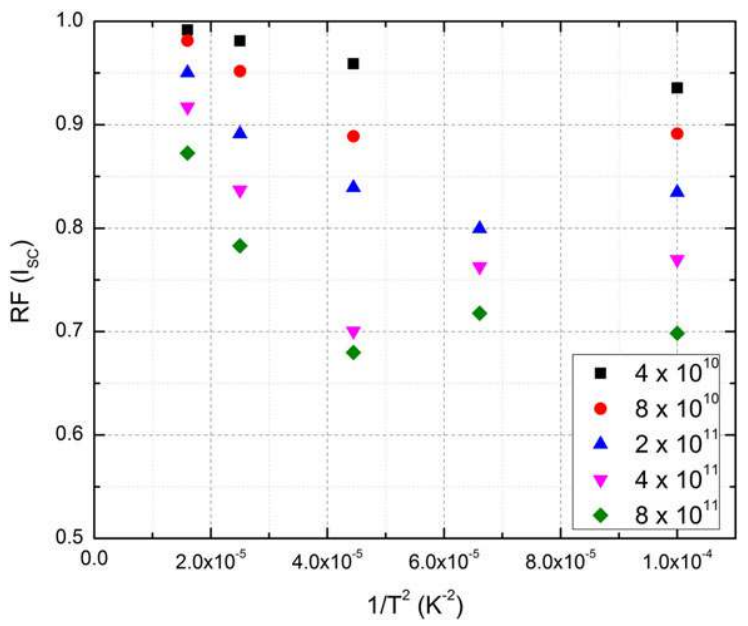

FIGURE $16 \mathrm{RF}\left(\mathrm{I}_{\mathrm{SC}}\right)$ versus $\mathrm{T}^{-2}$ of bottom component cells irradiated with various fluences $\left(\mathrm{cm}^{-2}\right)$ [Colour figure can be viewed at wileyonlinelibrary.com] easy. In BOL triple-junction lattice matched cells, at $300 \mathrm{~K}$ and below, the top subcell is current limiting. Proton irradiation significantly degrades the $I_{S C}$ of middle and bottom subcells resulting in the change of current limiting cell from top to middle or from top to bottom cell, depending on the temperature. The diagram of Figure 17 is an attempt to illustrate the expected temperature and proton fluence conditions indicating the nature of the limiting cell (note that Figure 17 necessitates considerably more data to be accurate).

\section{2 | Annealing}

The results describing the RFs of $\mathrm{I}_{\mathrm{SC}}, \mathrm{V}_{\mathrm{OC}}$, and $\mathrm{P}_{\mathrm{MAX}}$ following isochronal steps are given in Figure 10. From the variations of $I_{S C}$, it can be concluded that no significant defect annealing occurs in top and middle subcells in the range 100 to $300 \mathrm{~K}$. Defects in top cells irradiated with protons below $300 \mathrm{~K}$ have not been previously investigated; only preliminary results exist for electron irradiations. ${ }^{30-34}$ As shown in Figure 5 , at $100 \mathrm{~K}$, decreases of $4 \%$ of $\mathrm{I}_{\mathrm{SC}}$ and few $\%$ of $\mathrm{V}_{\mathrm{OC}}$ occur after the proton irradiation with a fluence of $1.6 \times 10^{12} \mathrm{~cm}^{-2}$. As to the middle subcell, the conclusion is consistent with previous studies on electron induced defects in $\mathrm{GaAs}^{35:}$ it has been established that in GaAs electron induced defects created at $4 \mathrm{~K}$ remain stable up to room temperature: no annealing stage should take place between 100 and $300 \mathrm{~K}$. As to bottom cells, the annealing stages we observed could correspond to the defects detected following low temperature electron irradiation. ${ }^{29}$

\subsection{Electric field dependence of defect recombination}

Besides the degradation induced by recombination of carriers generated by the illumination on the traps associated with the created defects, another type of degradation is observed, associated with the decrease of the photocurrent with increasing forward bias (see Figures 11 and 12). As demonstrated in Figure 12, this effect occurs

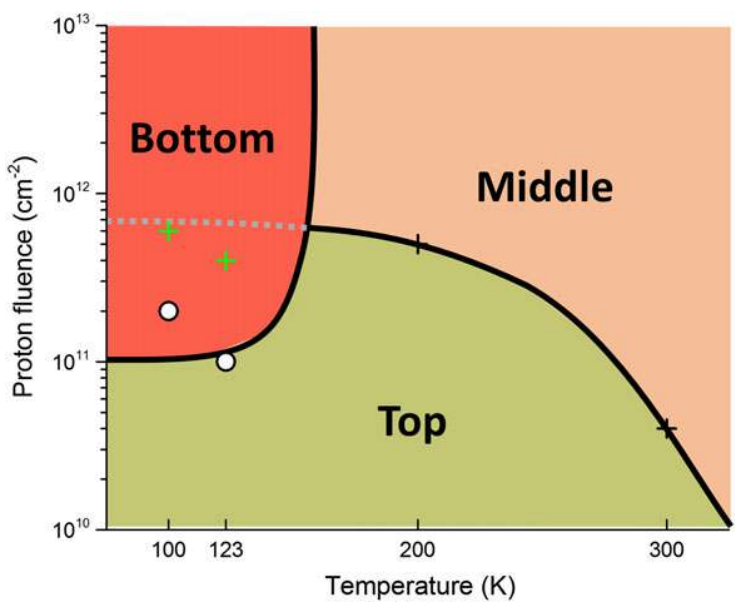

FIGURE 17 Fluence-temperature diagram indicating the regions in which a sub- cell is limiting the TJ cell: circle and cross symbols indicate transition points of current limiting from top to bottom and from top to middle subcell, respectively [Colour figure can be viewed at wileyonlinelibrary.com] 
only in the top and middle subcells, in agreement with the fact that no defects are created in the active region of the bottom cell.

We understand this phenomenon as being related to the effect of electric field on the capture rate of free carriers by defects, a consequence of the increase of the capture rate of carriers on the defects via the Poole-Frenkel effect. ${ }^{36}$ In other words, the photo-generated carrier has an enough kinetic energy to resist the coulombic attraction of a trap (defect site) induced by the irradiation when no external bias is applied ( $\mathrm{V}=0 \mathrm{~V})$. On the other hand, in positive biased conditions $(\mathrm{V}>0 \mathrm{~V})$, the carrier contains less kinetic energy compared to the zero bias condition (see Figure 18A,B). Therefore, the capture cross section of a minority carrier on a defect site, which results in carrier recombination and thus governs the collected photocurrent, depends on the electric field in the junction, ie, on the applied voltage. This phenomenon, which has been treated rigorously, ${ }^{37}$ can be illustrated schematically in the following way: free carriers in a depletion region have an energy which depends on temperature and electric field; they are captured by a defect when their energy becomes smaller than the attractive defect potential as illustrated in Figure 18C. For a Coulomb potential, the capture cross section varies as $\mathrm{V}^{-2}$ so that the trap assisted recombination current $I_{t r}$ increases with $V$. Similarly, when the higher bias is applied, the effective width of space charge region

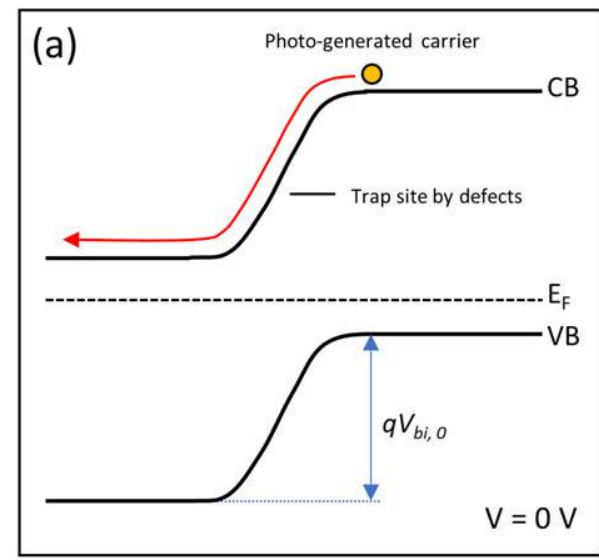

(b)
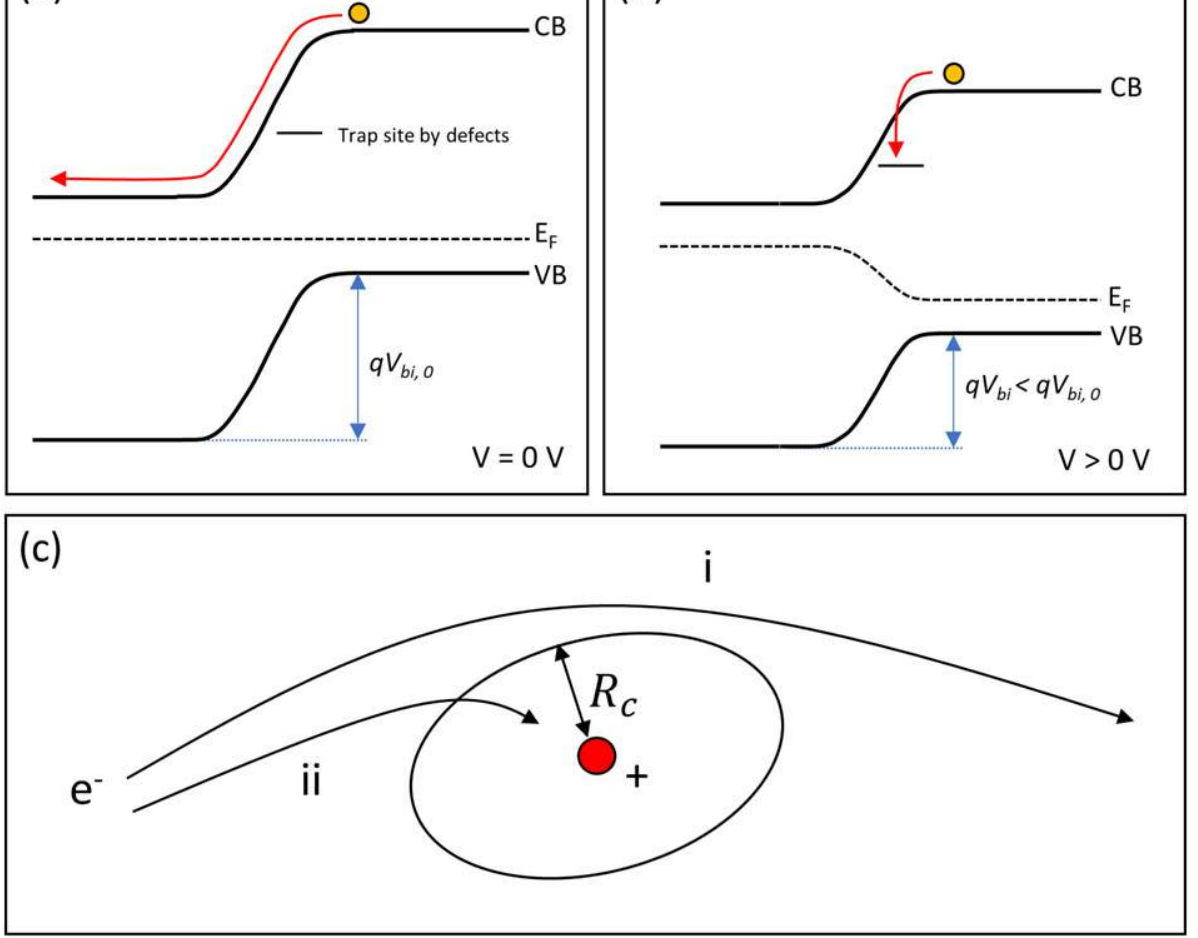

FIGURE 18 Simplified description of the electric field dependence of trap assisted recombination current ( $\left.I_{\text {tr }}\right)$-band diagram A, without bias, B, positive bias, and C, a simple diagram of the electric field dependent capture rate of carriers on defects [Colour figure can be viewed at wileyonlinelibrary.com]

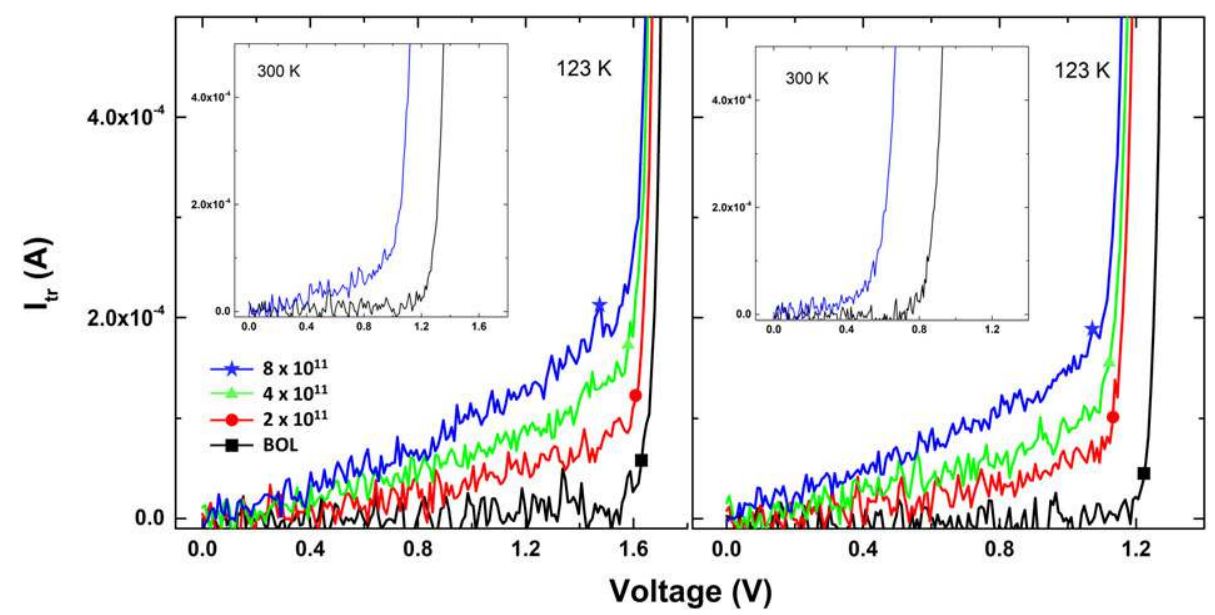

FIGURE 19 Voltage dependence of $\mathrm{I}_{\mathrm{tr}}$ of top (left) and middle (right) component cells irradiated at 123 and $300 \mathrm{~K}$ (inset) for different fluences [Colour figure can be viewed at wileyonlinelibrary.com] 
is shortened, which probably makes some of traps being located in the flat region and then becoming active for recombination.

The variation of trap assisted recombination current $\left(\mathrm{I}_{\mathrm{tr}}\right)$ as a function of $\mathrm{V}$ can be extracted from Figure 10 by subtracting a shifted DIV curve $\left(I_{\text {Dark }}+I_{S C}\right)$ from LIV one $\left(I_{\text {Light }}\right)$. We can evaluate the degradation factor induced by $I_{t r}$ at the point where the power is maximum. The effects of irradiation fluence and temperature are shown in Figure 19. Apparently, the amount of $I_{t r}$ depends on the fluence and the effects become smaller as the temperature increases. In the case of irradiation with a fluence of $8 \times 10^{11} \mathrm{~cm}^{-2}, \mathrm{P}_{\mathrm{MAX}}$ predicted from the shifted DIV curve and measured from the LIV curve are approximately 3.00 and $2.71 \mathrm{~mW}$ for the top component cell, and 1.98 and $1.79 \mathrm{~mW}$ for the middle cell. Therefore, the degradation factor of the $\mathrm{P}_{\text {MAX }}$ due to this effect is approximately $9.7 \%$ for the top cell and $9.6 \%$ for the middle cell, respectively.

This electric field effect is only observed in top and middle cells. It is not present in bottom cells because the irradiation induced defects are located in regions (cylinders around proton tracks) which do not participate to the active part of the cell.

\section{5 | CONCLUSION}

We irradiated TJ cells and associated component cells with various fluences of $1-\mathrm{MeV}$ protons in the range 300 to $100 \mathrm{~K}$. We verified that the I-V characteristics of the component cells are consistent with the reconstruction of the characteristics of the TJ cell, and consequently that the electrical properties of a TJ cell can be deduced from that of the component cells. The degradation of the current induced by the irradiation is due to the introduction of recombination centers but also, at low temperature, to the degradation of the FF as a result of the electric field dependence of the capture rates of minority carriers on the defects. The high degradation of the current in the bottom (Ge) cell can result in the TJ cell becoming bottom cell limited in certain EOL LILT conditions. It is the consequence of the fact that the distribution of the defects is not uniform, because they are decorating the proton tracks. The result is the formation of space charge regions, repelling free carriers and the degradation is primarily due to the reduction in the active area of the cell. This explanation allows to understand the peculiar difference observed between electron and proton irradiations performed on the same cells ${ }^{38:}$ a tunneling current is induced in electron irradiated cells (in which the defects are uniformly distributed), but not in proton irradiated ones (in which the defects are located in space charge regions, thus reducing the active area of the cell).

\section{ACKNOWLEDGEMENTS}

The present work is supported by the European Space Agency under contract no. 4000109645 . The irradiation has been performed in ARAMIS of SCALP facility of Centre de Sciences Nucléaires et de Sciences de la Matière and supported by EMIR federation (EMIR project no. 15-5727).

\section{ORCID}

Seonyong Park (D) http://orcid.org/0000-0001-9714-207X
Bruno Boizot (1) http://orcid.org/0000-0002-4613-9468

\section{REFERENCE}

1. Bett AW, Dimroth F, Guter W, Hoheisel R, Oliva E. Highest efficiency multi-junction solar cell for terrestrial and space applications. 24th European Photovoltaic Solar Energy Conference (EUPVSEC). September 2009.

2. Green MA, Emery K, Hishikawa Y, Warta W, Dunlop ED. Solar cell efficiency tables (version 45). Prog Photovolt Res Appl. 2014;23(1):1-9. https://doi.org/10.1002/pip.2573

3. Yamaguchi M, Okuda T, Taylor SJ, Takamoto T, Ikeda E, Kurita H. Superior radiation-resistant properties of $\mathrm{InGaP} / \mathrm{GaAs}$ tandem solar cells. Appl Phys Lett. 1997;70(12):1566-1568. https://doi.org/ 10.1063/1.118618

4. Dharmarasu N, Yamaguchi M, Khan A, et al. High-radiation-resistant InGaP, InGaAsP, and InGaAs solar cells for multijunction solar cells. Appl Phys Lett. 2001;79(15):2399-2401. https://doi.org/10.1063/ 1.1409270

5. Imaizumi M, Takamoto T, Sumita T. Study of radiation response on single-junction component sub-cells in triple-junction solar cells. 3rd World Conference on Photovoltaic Solar Energy Conversion 2003:599-602.

6. Gauffier A, Gauffier A, David JP, Gilard O, David JP, Gilard O. Analytical model for multi-junction solar cells prediction in space environment. Microelectron Reliab. 2008;48(8-9):1494-1499. https://doi. org/10.1016/j.microrel.2008.07.049

7. Rong $\mathrm{W}$, Yunhong L, Xufang S. Effects of $0.28-2.80 \mathrm{MeV}$ proton irradiation on GalnP/GaAs/Ge triple-junction solar cells for space use. Nucl Instrum Methods Phys Res, Sect B. 2008;266(5):745-749. https://doi. org/10.1016/j.nimb.2007.12.076

8. Sato S-I, Ohshima T, Imaizumi M. Modeling of degradation behavior of InGaP/GaAs/Ge triple-junction space solar cell exposed to charged particles. J Appl Phys. 2009;105(4):044504. https://doi.org/10.1063/ 1.3079522

9. Elfiky D, Yamaguchi M, Sasaki T, et al. Study the effects of proton irradiation on $\mathrm{GaAs} / \mathrm{Ge}$ solar cells. IEEE 35th Photovoltaic Specialists Conference (PVSC) 2010:002528-002532. doi:https://doi.org/ 10.1109/PVSC.2010.5614633.

10. Xin G, Zhan-zu F, Xin-yu C, Sheng-sheng Y, Lei Z. Performance evaluation and prediction of single-junction and triple-junction GaAs solar cells induced by electron and proton irradiations. IEEE Trans Nucl Sci. 2014;61(4):1838-1842. https://doi.org/10.1109/TNS.2014.2306991

11. Hoheisel R, Scheiman D, Messenger S, Jenkins P, Walters R. Detailed characterization of the radiation response of multijunction solar cells using electroluminescence measurements. IEEE Trans Nucl Sci. 2016;62(6):2894-2898. https://doi.org/10.1109/TNS.2015.2498838.

12. Gelderloos CJ, Miller KB, Walters RJ, Summers GP, Messenger SR. Low intensity low temperature performance of advanced solar cells. IEEE 29th Photovoltaic Specialists Conference (PVSC) 2002:804-807. doi: https://doi.org/10.1109/pvsc.2002.1190695.

13. Stella P, Davis G, Mueller R, Distefano S. The environmental performance at low intensity, low temperature (LILT) of high efficiency triple junction solar cells. 2nd International Energy Conversion Engineering Conference 2004. doi:https://doi.org/10.2514/6.20045579.

14. Stella PM, Mueller RL, Scrivner RL, Helizon RS. Preliminary low temperature electron irradiation of triple junction solar cells. 19th Space Photovoltaic Research and Dent Tech. 2007;1-7. https://ntrs.nasa.gov/ search.jsp? $\mathrm{R}=20090022291$

15. Ohshima T, Sumita T, Imaizumi M. Evaluation of the electrical characteristics of III-V compounds solar cells irradiated with protons at low temperature. IEEE 35th Photovoltaic Specialists Conference (PVSC). 2005:806-809. doi:https://doi.org/10.1109/PVSC.2005.1488255.

16. Harris RD, Imaizumi $M$, Walters RJ, et al. In situ irradiation and measurement of triple junction solar cells at low intensity, low 
temperature (LILT) conditions. IEEE Trans Nucl Sci. 2008;55(6):35023507. https://doi.org/10.1109/TNS.2008.2006971

17. Baur C, Khorenko V, Siefer G, et al. Development status of triplejunction solar cells optimized for low intensity low temperature applications. IEEE 39th Photovoltaic Specialists Conference (PVSC) 2013:3237-3242. doi:https://doi.org/10.1109/pvsc.2013.6745142.

18. Bourgoin JC, Boizot B, Khirouni K, Khorenko V. On the prediction of solar cell degradation in space. 10th European Space Power Conference (ESPC) 2014;719:1.

19. Taylor S, Baur C, Torunski T, et al. Performance of European Triple-Junction Solar Cells for Deep Space Missions 8th European Space Power Conference (ESPC) 2008;661:34-39.

20. Baur C, Khorenko V, Siefer G, Inguimbert V, Park S, Boizot B, Bourgoin JC, Casale M, Campesato R, Schnell HG, Gerhard A, Zanella P, Ferrando E, Reutenauer X, Bongers E, Gras A Status of solar generator related technology development activities supporting the juice mission. Fernandez a, ed. E3S Web Conf. 2017;16(8):04005-04008. doi: https://doi.org/10.1051/e3sconf/20171604005.

21. Park S, Bourgoin JC, Cavani O, Khorenko V, Baur C, Boizot B. Space degradation of $3 \mathrm{~J}$ solar cells: II-electron irradiation. to be published.

22. Nubile P, Nubile P, Bourgoin JC, Stievenard D, Deresmes D, Strobl G. Defects in low-temperature electron-irradiated p-type silicon. J Appl Phys. 1992;72(7):2673-2679. https://doi.org/10.1063/1.351516

23. Zazoui M, Zaidi MA, Bourgoin JC, Strobl G. Recombination centers in Czochralski-grown p-Si. J Appl Phys. 1993;74(6):3944-3947. https:// doi.org/10.1063/1.354461.

24. Zazoui M, Bourgoin JC, Deresmes D, Strobl G. Recombination centers in electron-irradiated Czochralski silicon solar cells. J Appl Phys. 1994;76(2):815-819. https://doi.org/10.1063/1.357755

25. Ziegler JF, Ziegler MD, Biersack JP. SRIM-the stopping and range of ions in matter (2010). Nuclear Inst and Methods in Physics Research, B. 2010;268(11-12):1818-1823. https://doi.org/10.1016/j. nimb.2010.02.091

26. Baur C, Meusel M, Dimroth F, Bett AW. Investigation of Ge component cells. IEEE 31st Photovoltaic Specialists Conference (PVSC) 2005:675-678. doi:https://doi.org/10.1109/PVSC.2005.1488221.

27. Singh $P$, Ravindra NM. Temperature dependence of solar cell performance-an analysis. Sol Energy Mater Sol Cells. 2012;101(C:36-45. https://doi.org/10.1016/j.solmat.2012.02.019

28. Boschini MJ, Rancoita PG, Tacconi M. SR-NIEL Calculator: screened relativistic (SR) treatment for calculating the displacement damage and nuclear stopping powers for electrons, protons, light- and heavyions in materials (Version 393). October 2017. http://www.sr-niel. org/.
29. Bourgoin JC, Mooney PM, Poulin F. Defects and radiation effects in semiconductors. In: Inst. Phys. Conf. Ser. Hasiguti RR, ed. Vol 59. 1980:33.

30. Zaidi MA, Zazoui M, Bourgoin JC. Defects in electron irradiated GalnP. J Appl Phys. 1993;73(11):7229-7231. https://doi.org/10.1063/ 1.354009

31. Khan A, Khan A, Yamaguchi M, et al. Recombination centers in electron irradiated GalnP: application to the degradation of space solar cells. J Cryst Growth. 2000;210(1-3):264-267. https://doi.org/ 10.1016/s0022-0248(99)00693-4

32. Khan A, Yamaguchi M, Bourgoin JC, Bourgoin JC, Takamoto T. Thermal annealing study of $1 \mathrm{MeV}$ electron-irradiation-induced defects in $n+p$ InGaP diodes and solar cells. J Appl Phys. 2002;91(4):2391-2397. https://doi.org/10.1063/1.1433936

33. Khan A, Yamaguchi M, Dharmaso N, Bourgoin J, Ando K, Takamoto T. Deep level transient spectroscopy analysis of $10 \mathrm{MeV}$ proton and 1 $\mathrm{MeV}$ Electron irradiation-induced defects in $\mathrm{p}-\operatorname{lnGaP}$ and InGaP-based solar cells. Jpn J Appl Phys. 2002;41(3):1241-1246. https://doi.org/ 10.1143/JJAP.41.1241

34. Dharmarasu N, Yamaguchi M, Bourgoin JC, et al. Majority- and minority-carrier deep level traps in proton-irradiated $\mathrm{n}+/ \mathrm{p}$-InGaP space solar cells. Appl Phys Lett. 2002;81(1):64-66. https://doi.org/10.1063/ 1.1491005

35. Pons D, Bourgoin JC. Irradiation-induced defects in GaAs. J Phys C: Solid State Phys. 1985;18(20):3839-3871. https://doi.org/10.1088/ 0022-3719/18/20/012

36. Zaidi MA, Bourgoin JC, Maaref $\mathrm{H}$. Poole-Frenkel-assisted emission from deep levels in electron-irradiated germanium. Semicond Sci Technol. 1989;4(9):739-742. https://doi.org/10.1088/0268-1242/4/ 9/006

37. Vincent G, Chantre A, Bois D. Electric field effect on the thermal emission of traps in semiconductor junctions. J Appl Phys. 1979;50(8):54845487. https://doi.org/10.1063/1.326601

38. Park S, Bourgoin JC, Cavani O, Khorenko V, Baur C, Boizot B. Origin of the degradation of triple junction solar cells at low temperature. Fernandez a, ed. E3S Web Conf 2017;16(1):04004-04004. doi: https://doi.org/10.1051/e3sconf/20171604004. 